\title{
Preliminary Geospatial Analysis of Arctic Ocean Hydrocarbon Resources
}

\author{
P.E. Long \\ S.K. Wurstner \\ E.C. Sullivan \\ H.T. Schaef \\ D.J. Bradley
}

October 2008

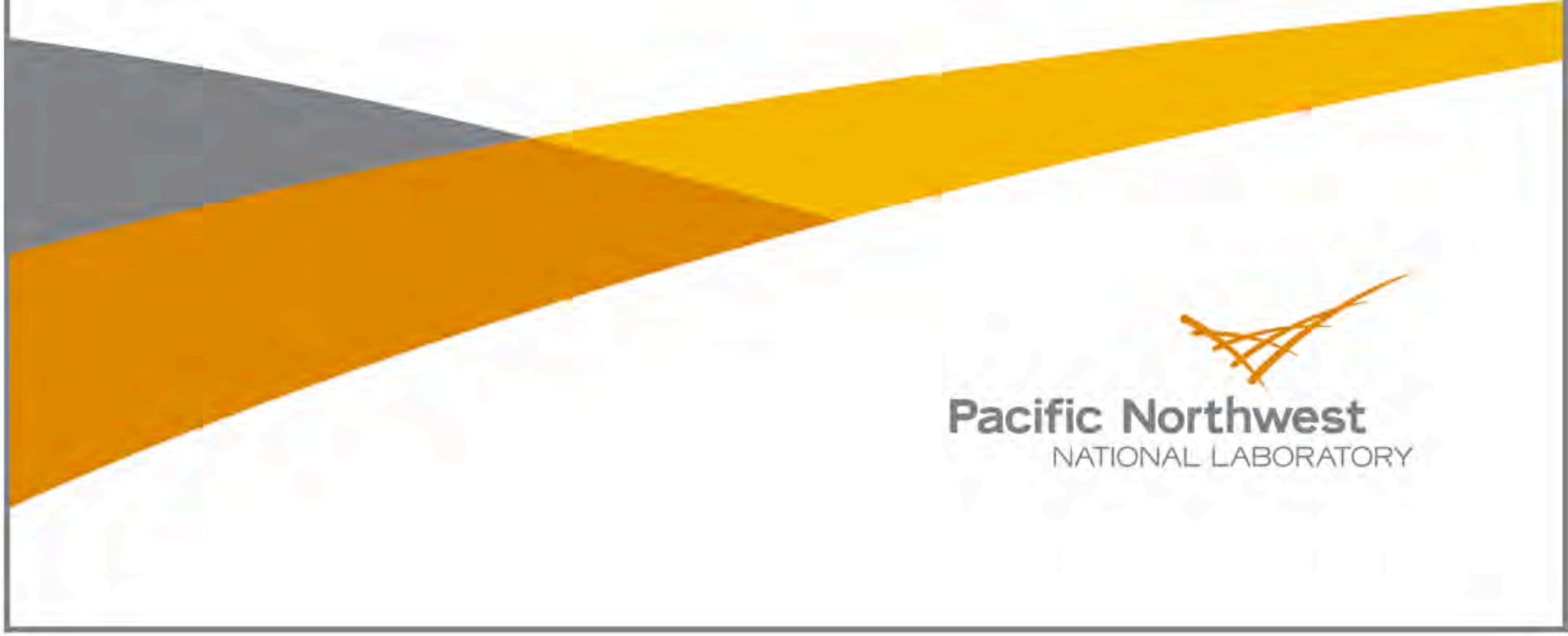





\title{
DISCLAIMER
}

This report was prepared as an account of work sponsored by an agency of the United States Government. Neither the United States Government nor any agency thereof, nor Battelle Memorial Institute, nor any of their employees, makes any warranty, express or implied, or assumes any legal liability or responsibility for the accuracy, completeness, or usefulness of any information, apparatus, product, or process disclosed, or represents that its use would not infringe privately owned rights. Reference herein to any specific commercial product, process, or service by trade name, trademark, manufacturer, or otherwise does not necessarily constitute or imply its endorsement, recommendation, or favoring by the United States Government or any agency thereof, or Battelle Memorial Institute. The views and opinions of authors expressed herein do not necessarily state or reflect those of the United States Government or any agency thereof.

\author{
PACIFIC NORTHWEST NATIONAL LABORATORY \\ operated by \\ BATTELLE \\ for the \\ UNITED STATES DEPARTMENT OF ENERGY \\ under Contract DE-AC05-76RL01830
}

Printed in the United States of America
Available to DOE and DOE contractors from the Office of Scientific and Technical Information,
P.O. Box 62, Oak Ridge, TN 37831-0062;
ph: (865) 576-8401
fax: $(865) 576-5728$
email: reports@adonis.osti.gov

\footnotetext{
Available to the public from the National Technical Information Service, U.S. Department of Commerce, 5285 Port Royal Rd., Springfield, VA 22161 ph: (800) 553-6847 fax: $(703) 605-6900$ email: orders@ntis.fedworld.gov online ordering: http://www.ntis.gov/ordering.htm
}

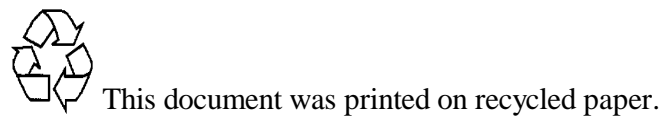





\title{
Preliminary Geospatial Analysis of Arctic Ocean Hydrocarbon Resources
}

\author{
P.E. Long \\ S.K. Wurstner \\ E.C. Sullivan \\ H.T. Schaef \\ D.J. Bradley
}

October 2008

Prepared for

the U.S. Department of Energy

under Contract DE-AC05-76RL01830

Pacific Northwest National Laboratory

Richland, Washington 99352 



\section{Summary}

Ice over the Arctic Ocean is predicted to become thinner and to cover less area with time (NASA, 2005). The combination of more ice-free waters for exploration and navigation, along with increasing demand for hydrocarbons and improvements in technologies for the discovery and exploitation of new hydrocarbon resources have focused attention on the hydrocarbon potential of the Arctic Basin and its margins. The purpose of this document is to 1) summarize results of a review of published hydrocarbon resources in the Arctic, including both conventional oil and gas and methane hydrates and 2) develop a set of digital maps of the hydrocarbon potential of the Arctic Ocean. These maps can be combined with predictions of ice-free areas to enable estimates of the likely regions and sequence of hydrocarbon production development in the Arctic.

In this report, conventional oil and gas resources are explicitly linked with potential gas hydrate resources. This has not been attempted previously and is particularly powerful as the likelihood of gas production from marine gas hydrates increases. Available or planned infrastructure, such as pipelines, combined with the geospatial distribution of hydrocarbons is a very strong determinant of the temporalspatial development of Arctic hydrocarbon resources.

Significant unknowns decrease the certainty of predictions for development of hydrocarbon resources. These include: 1) Areas in the Russian Arctic that are poorly mapped,2) Disputed ownership: primarily the Lomonosov Ridge, 3) Lack of detailed information on gas hydrate distribution, and 4) Technical risk associated with the ability to extract methane gas from gas hydrates. Logistics may control areas of exploration more than hydrocarbon potential. Accessibility, established ownership, and leasing of exploration blocks may trump quality of source rock, reservoir, and size of target. With this in mind, the main areas that are likely to be explored first are the Bering Strait and Chukchi Sea, in spite of the fact that these areas do not have highest potential for future hydrocarbon reserves.

Opportunities for improving the mapping and assessment of Arctic hydrocarbon resources include: 1) refining hydrocarbon potential on a basin-by-basin basis, 2) developing more realistic and detailed distribution of gas hydrate, and 3) assessing the likely future scenarios for development of infrastructure and their interaction with hydrocarbon potential. It would also be useful to develop a more sophisticated approach to merging conventional and gas hydrate resource potential that considers the technical uncertainty associated with exploitation of gas hydrate resources. Taken together, additional work in these areas could significantly improve our understanding of the exploitation of Arctic hydrocarbons as ice-free areas increase in the future. 


\section{Key Findings}

Overall conclusions from this study are as follows:

- Geographic areas with the highest hydrocarbon potential are Arctic Alaska, eastern Greenland, the East and West Barents basins in Norway and Russia, and the South Kara/Yamal basins of Russia.

- Global interest in Arctic hydrocarbon resources is dynamic, increasing dramatically as global demand for hydrocarbon resources increases.

- The Arctic contains $\sim 13 \%$ of global undiscovered oil, $\sim 30 \%$ of global undiscovered conventional natural gas, and as much as one third of global gas hydrate.

- Geospatial analysis of marine Arctic hydrocarbon resources can be linked to progressively icefree areas enabling estimation of possible development areas.

- The rate and location of future hydrocarbon exploration activities will depend not only on richness of hydrocarbon potential, Arctic ice, and potential for supporting infrastructure, but also on the opening of areas by various governments for industry exploration.

- Current infrastructure is well known. However, future infrastructure is partly controlled by geopolitics and governmental decisions, making it difficult to predict. The most significant areas are those with both highest hydrocarbon potential and the best current and planned infrastructure.

- Depth of water is critical in the economics of exploration and development; the shallow continental shelf is not only more attractive economically, it is also where the greatest hydrocarbon potential is located, including gas hydrates. 


\section{Contents}

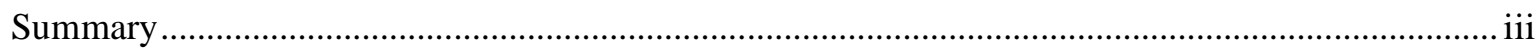

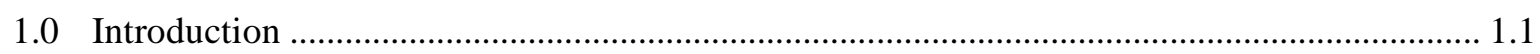

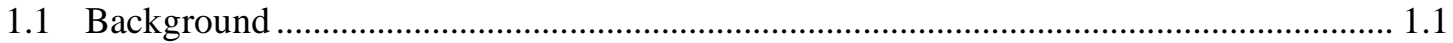

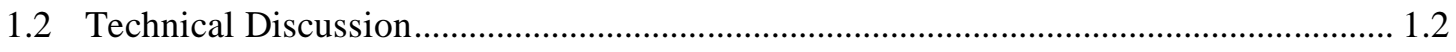

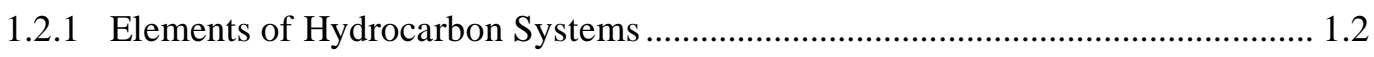

1.2.2 Petroleum Geology of the Arctic Ocean............................................................. 1.2

2.0 Review of Published Potential Hydrocarbon Resource Assessments..................................... 2.1

2.1 United States Geological Survey Oil and Gas Assessment .............................................. 2.1

2.2 Wood Mackenzie and Fugro Robertson Assessment ....................................................... 2.3

2.3 Comparison of USGS and Wood Mackenzie Assessments ............................................. 2.3

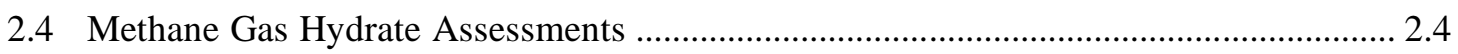

3.0 Geospatial Analysis of Potential Hydrocarbon Resources ....................................................... 3.1

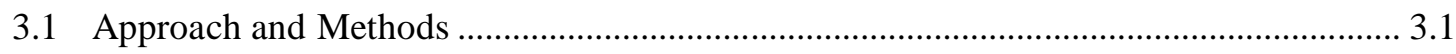

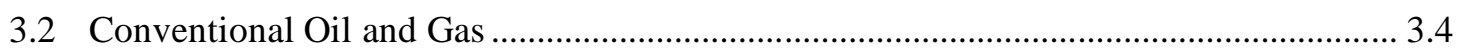

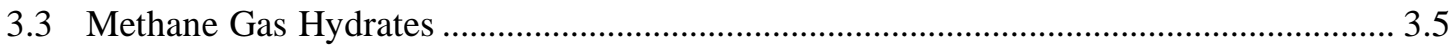

3.4 Combining Conventional Oil and Gas with Methane Gas Hydrate Resources ................ 3.8

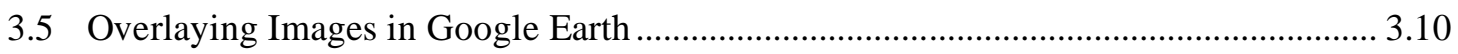

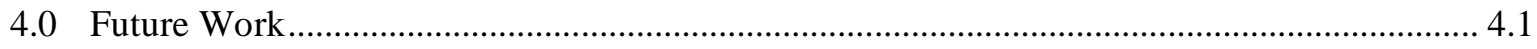

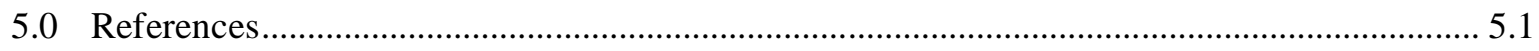

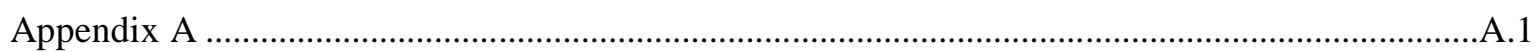




\section{Figures}

Figure 1.1. Tectonic elements of the Arctic Ocean (based on data from Jakobsson, et al., 2008).. 1.3

Figure 2.1. Two of the Arctic regions assessed for undiscovered hydrocarbon resources by the

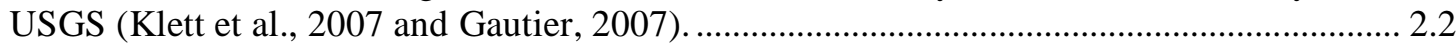

Figure 2.2. Offshore areas assessed by the USGS for in-place volumes of methane gas hydrates (Collett, 1995).

Figure 3.1. Bathymetry and Topography of the Arctic Region (based on data from Jakobsson, et al., 2008).

Figure 3.2. Geologic Provinces with possibility of oil and gas resources and areas of igneous rock outcrops representing unlikely hydrocarbon occurrence (based on digital data from Persits

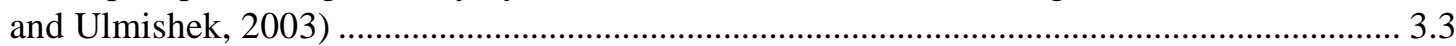

Figure 3.3. Conventional Oil and Gas Potential of Undiscovered Fields in Gboe per field........... 3.4

Figure 3.4 Arctic gas hydrate potential (from Wood and Jung, 2008) shown as an estimated thicknes of the gas hydrate stability zone in marine sediments................................................. 3.5

Figure 3.5. Index map of investigation area (taken from Romanovskii et al., 2005) ..................... 3.6

Figure 3.6. Bathymetric Ranges Defining Continental Shelf Regions with Gas Hydrate Potential Associated with Submarine Permafrost ................................................................................. 3.7

Figure 3.7. Hydrocarbon potential showing combined methane hydrate and conventional oil and gas potential.

\section{Tables}

Table 2.1. Estimates of undiscovered hydrocarbon potential for some of the circum Arctic shelf areas.

Table 2.2. Estimates of Gobal Oceanic Reserves of Methane in Natural Gas Hydrates in 100,000

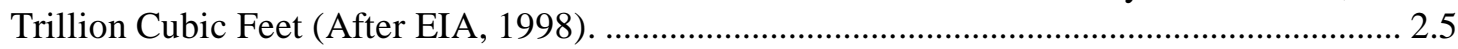

Table A.1. Index of electronic files provided on accompanying CD ............................................1 


\subsection{Introduction}

\subsection{Background}

Arctic Ocean ice has been thinning and occupying less area over the last few decades and this trend is expected to continue in response to global climate change (NASA, 2005). The combination of more icefree waters for exploration and navigation, along with increasing demand for hydrocarbons and improvements in technologies for the discovery and exploitation of new hydrocarbon resources have focused attention on the hydrocarbon potential of the Arctic Basin and its margins. The purpose of this document is to 1) summarize results of a review of published hydrocarbon resources in the Arctic, including both conventional oil and gas and methane hydrates and 2) develop a set of digital maps of the hydrocarbon potential of the Arctic Ocean. These maps can then be combined with predictions of ice-free areas to enable estimates of the likely regions and sequence of hydrocarbon production development in the Arctic region.

At the present time there are over 550 oil and gas fields in the Arctic, primarily in northern Alaska, the East Barents Sea, and the Russian Kara and Yamal Basins. Gas resources dominate over oil in much of the Arctic Basin including the Chukchi Sea, the Mackenzie Delta and the Russian shelf. The rate and location of future exploration activities will depend not only on richness of hydrocarbon potential and potential for supporting infrastructure, but also on the opening of areas by various governments for industry exploration. An example of the impact of government decisions is the intense activity connected to the February 6, 2008 lease sale in the Chukchi area by the U.S. Minerals Management Service. The expenditure of $\$ 3.4$ billion by exploration companies for offshore tracts will be followed by seismic acquisition and drilling. Pre-drilling evaluation of acreage may take as little as 2-3 years; Shell has successfully drilled and tested the Burger well (estimated reserves of 14 trillion cubic feet (TCF) of natural gas plus potential pay in additional shallow horizons) on one of the structures. The 29.4 million acres in the lease sale are estimated to contain 15 billion barrels of oil and 77 TCF of gas (Friend, 2008). This is not an area of the greatest hydrocarbon potential or of existing infrastructure, but it is an area of good accessibility, current leasing activity, and proven hydrocarbons.

In this context, there are five nations claiming hydrocarbon resources in the Arctic Ocean. The International Boundaries Research Unit at Durham University has extensively researched these claims (IBRU, 2008, see http://www.dur.ac.uk/ibru/resources/arctic/). Conflicting national claims underscore the importance of these resources to the future global economy as world hydrocarbon resources are strained under the energy demands of developing nations. A multinational approach has been taken by the Arctic Oil and Gas Company (AOAG.PK, http://www.arcticoag.com/). The company made an Exclusive Rights Claim to the Hydrocarbon Resources of the Arctic Oceans Commons with the United Nations and the five Arctic countries on May 9th 2006. The company plans to form a multinational joint venture consortium of major oil companies. It is highly uncertain if the exclusive rights or the formation of a joint venture consortium will be successful; the existence of the company and its claim illustrates the complexity of competing national and corporate entities for exploitation of Arctic hydrocarbons.

Conventional hydrocarbon potential of the shallow parts of the Arctic continental shelf may be enhanced by the near-surface presence of methane clathrates (also called methane hydrates or gas hydrates - for simplicity we will use the term gas hydrates for the remainder of this report). Gas hydrates are solids composed of crystalline cage-like molecular structures of water that each surround a gas molecule, (mostly methane, but also propane, ethane, and carbon dioxide). This hydrocarbon resource forms dominantly from microbial (biogenic) degradation of organic material, but also from thermogenic 
methane from deep, conventional hydrocarbon accumulations. An estimated $400 \mathrm{Gt}$ of carbon in the form of natural gas in hydrate form may exist in sub-oceanic sediments and arctic permafrost zones, where conditions of pressure and temperature are within the hydrate stability region (Max, 2000; Kvenvolden, 1995; Sloan, 1997). However, global estimates of gas hydrate abundance have been controversial and generally declining with time. Specific reservoir conditions and gas hydrate concentrations are more important to the eventual production of methane gas from gas hydrate than the global amount of methane in gas hydrates.

Technology to extract methane gas from natural gas hydrates is currently under development, and several countries (United States, India, Canada, Japan, and South Korea) have established national gas hydrate programs with production goals as early as 2017. As fossil energy resources become scarcer, natural gas hydrate deposits are expected to become economically viable alternatives to conventional oil and gas reservoirs.

\subsection{Technical Discussion}

\subsubsection{Elements of Hydrocarbon Systems}

The six main elements of conventional petroleum systems are reservoirs, traps, seals, source rocks, hydrocarbon generation, migration, and the timing of development of each of the other elements. Identification of source rock facies, distribution and maturity, the timing of trap and seal development, along with the pressure, volume and temperature (PVT) characteristics of generated hydrocarbons help to constrain the migration path and quantity of hydrocarbons that accumulate in a trap. The success of locating hydrocarbon accumulations depends on understanding the geologic processes controlling basin formation and fill, and includes regional tectonics, climate, and sediment supply, as well as the geochemistry of rocks and fluids. First order models predict a relatively simple hydrocarbon distribution, controlled largely by the presence of mature source rocks in areas of thick sedimentary rocks, with favorable timing of hydrocarbon generation (hydrocarbon charge) relative to trap development. Refinements of that simple paradigm have evolved to include complex migration histories and trapping mechanisms that are now thought to be major controls on hydrocarbon type, quality, and distribution.

Tools and technologies for predicting and evaluating conventional hydrocarbon accumulations have also greatly improved over the last 20 years. A similar approach is now applied to gas hydrate reservoirs recognizing that there are differences in accumulation mechanisms for gas hydrate systems and that most gas hydrate systems form from biogenic methane and are geologically young relative to most conventional petroleum hydrocarbon systems.

\subsubsection{Petroleum Geology of the Arctic Ocean}

The distribution of source rock, reservoirs, traps and seals are strongly controlled by the tectonic history of the Arctic Basin and the distribution of sedimentary rocks that contain the hydrocarbon resources. In this section, we review the geologic history of the Arctic Basin, which includes the origin, distribution and relative thickness of sedimentary rock.

\subsubsection{Tectonic History of the Arctic Basin}

The geology of the Arctic Ocean is dominated by the Amerasia and Eurasia basins, which are separated by the Lomonosov Ridge (Figure 1.1). Although considered to be international territory since 1997 (at 
which time the U.N. Convention on the Law of the Sea was ratified by 152 nations), a team of Russian scientists reported in June of 2007 that new evidence showed that Russia's Arctic region is connected to the North Pole by the Lomonosov Ridge (Gramling, 2007). This resulted in the still-disputed claim that Russia controls this territory and the natural resources within it.

Most of the oceanic crust in the Arctic basins is Cretaceous and Cenozoic in age and was generated by the active Gakkel spreading ridge, which is a northward migrating extension of the mid-Atlantic Ridge (Whaley, 2007a). Early to middle Paleozoic continental collision of the plates surrounding the Arctic produced mountain belts and most of the economic basement. Regional subsidence during the Triassic and Jurassic produced important source rocks and reservoirs for most of the discovered and yet-to-be discovered hydrocarbon accumulations. Late Jurassic opening of the Canada sub-basin in the Amerasia basin was accompanied by mountain building in Alaska and maturation and migration of hydrocarbons toward Prudhoe Bay. During this time, erosion of the Canadian Rockies produced the large Mackenzie Delta depocenter (area of maximum sediment thickness).

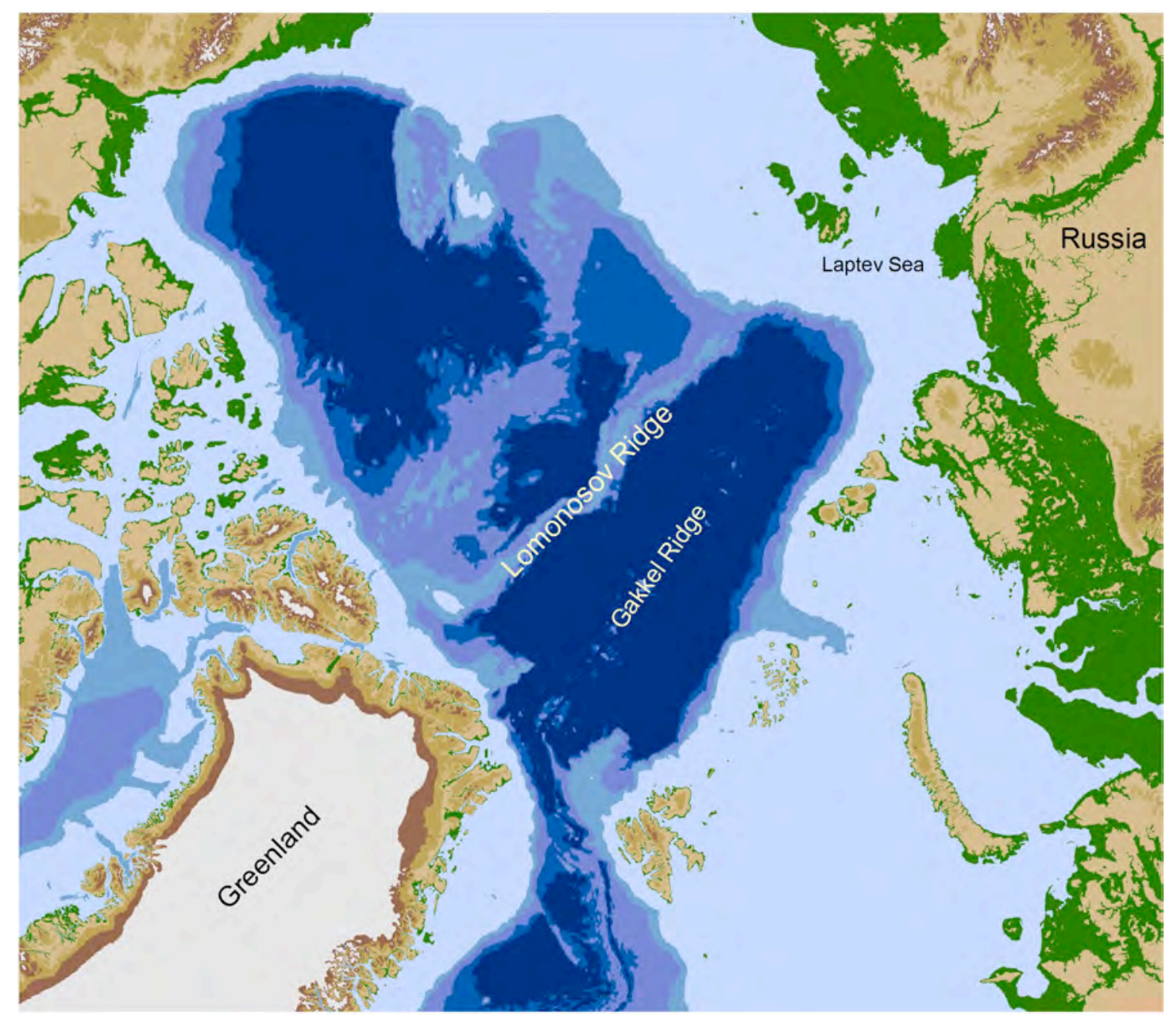

Figure 1.1. Tectonic elements of the Arctic Ocean (based on data from Jakobsson, et al., 2008)

The early opening of the Amerasia basin initiated with the Late Cretaceous migration of the mid Atlantic Ridge between Greenland and Canada, and was followed by extension between Greenland and Spitsbergen. Late Cretaceous sea floor spreading occurred parallel to the Canadian Arctic border, and was 
accompanied by the migration of the Chukchi Borderland along transform faults, and the formation of a triple junction within the basin, forming the Alpha-Mendeleev Ridge. This extinct spreading center may consist of continental crust that originated adjacent to the Lomonosov Ridge, plus thick post-Cretaceous sediment (Max, 2000).

Sea floor spreading along the Gakkel Ridge commenced at the end of the Paleocene, and the Lomonosev Ridge was rifted away from the continental crust of the Barents Sea, toward the North Pole. This rifting was accompanied by subsidence of the Ridge, and has accelerated since the Miocene. Miocene pole-ward extension of oceanic and continental crust also occurred from Greenland to the Beaufort Sea, as well as between the Alaskan and Siberian Peninsulas.

The plate tectonic model of the Arctic Basin was redefined by GETECH (Whaley, 2007a) using an extensive commercial library of gravity and magnetic data. The hydrocarbon potential based on this redefined model can be associated with the following implications:

- The Chukchi Borderland is expected to have stratigraphic similarities to the North Slope of Alaska and the Arctic Canadian islands.

- The Alpha-Mendeleev (A-M) Ridge may contain continental crust related to the Lomonosov Ridge. Up to 6,000 m of post mid Cretaceous sediments may be present along the Alaska-facing flank of the A-M Ridge (Max, 2000).

- The Lomonosov Ridge has been a sediment-starved continental margin during the Cenozoic but consists of older continental crust that, which, according to the U. S. Geological Survey, may contain up to 10 billion barrels of oil.

- Depth to the oil generation window in the Arctic Basin is generally about $2700 \mathrm{~m}$. Unless sediments have been buried to that depth they are not likely to have sourced hydrocarbons. This has important implications for the Arctic-wide Eocene Azolla source rock interval (Whaley, 2007b).

- The Canada, Amundsen and Nansen basins are sediment starved. They are not expected to have enough sediment to bury potential source rocks into the oil-maturation window.

- The northeast side of Greenland has several basins including rift and salt basins with highly prospective accumulations of sedimentary rock.

\subsubsection{Summary of the Tectonics and Petroleum Geology of the Arctic Basin}

The most important controls on the petroleum geology of the Arctic Ocean include the pre-Cenozoic history of deformation of the region surrounding the Arctic Ocean and the generally passive margin tectonics from the Jurassic until Recent. Jurassic subsidence produced important source rocks. The Late Cretaceous opening of the Arctic Ocean produced epicontinental rifts and important depocenters of the Mackenzie Delta and the northeastern part of the East Siberian Shelf (Franke et al., 2004). Gas reserves dominate over oil. Plate tectonic activities outside of the Arctic Basin have influenced not only the sediment source (the Canadian Rockies) for the formation of depocenters such as the Mackenzie Delta, but also many of the relatively gentle structural features that form traps in Chukchi and elsewhere. The most prospective areas of the circum Arctic Ocean are the Arctic Alaska, eastern Greenland, the East and West Barents basins in Norway and Russia, and the South Kara/Yamal basins of Russia. Most of these have Jurassic oil and gas in structures that formed as a result of the opening of the Arctic. Structures in the Barents Sea have reservoirs as old as Triassic; source rocks of the unexplored Laptev Basin are expected to be Permian-Triassic (Dongarov, 2007). Post Cretaceous sedimentation rates outside of a few 
localized Arctic depocenters are relatively low, and low volumes of hydrocarbons are expected to have matured or migrated during the Cenozoic: thus most of the oil in the Arctic occurs in older rocks but may also have migrated into traps that formed as a result of Cenozoic tectonics. The youngest source rock across the Arctic is the Eocene Azolla interval, formed by the prolific freshwater floating fern Azolla during a time when the Arctic was largely enclosed, with elevated temperatures and a freshwater surface layer. The ability of this zone to source hydrocarbon accumulation is largely related to thickness of overburden (Whaley, 2007b).

The tectonics and geology controlling the occurrence of gas hydrates is markedly different from conventional petroleum resources. Most gas hydrate forms from biogenic as opposed to thermogenic methane based on the carbon isotopic signature of methane in gas hydrate. Furthermore, gas hydrate are only stable in low temperature-high pressure environment, e.g. shallow marine sediments, a few to several hundred meters below seafloor. Arctic marine permafrost relic from glacial low stands of sea level enhances the formation of gas hydrate. Both passive and convergent continental margins host voluminous gas hydrate deposits. The combination of depressed subseafloor isotherms and extensive passive margin continental shelf sediments has led to long-standing predictions of gas hydrate in the Arctic Ocean (Max and Lowrie 1993, Romanovskii et al. 2005). Recent estimates of Arctic gas hydrate locations have also focused on gas hydrate stability in the context of sediment deposition thickness (Wood and Jung 2008) and on submarine as well as terrestrial permafrost accumulations (Collett (2008). 



\subsection{Review of Published Potential Hydrocarbon Resource Assessments}

Hydrocarbon resource assessments by government agencies and private corporations have been ongoing for decades, but the focus has often been in areas more accessible than the Arctic region. However, as demand for hydrocarbons increases, assessment of additional areas becomes critical. This section summarizes several of the hydrocarbon resource assessments conducted for the Arctic region.

\subsection{United States Geological Survey Oil and Gas Assessment}

The USGS has been undertaking hydrocarbon resource assessments for more than 30 years. These assessments are based on the identification of hydrocarbon plays and the evaluation of each geologic element of the Total Petroleum Systems defined in a given hydrocarbon province, and includes hydrocarbon source rocks (source-rock type and maturation and hydrocarbon generation and migration), reservoir rocks (sequence stratigraphy and petrophysical properties), and hydrocarbon traps (trap formation and timing). Using this geologic framework, the USGS evaluates and estimates remaining technically producible hydrocarbons (known) and undiscovered oil and gas resources as well as hypothetical petroleum systems and their recoverable reserves.

The initial step of an assessment involves defining the hydrocarbon plays. A play is a volume of rock that contains similar geological parameters (such as petroleum charge, reservoir, and trap) that determine petroleum (crude oil, natural gas, and natural gas liquids) potential. For each play, distributions of the number and size of potential petroleum accumulations are estimated, using a probabilistic range of values for attributes such as reservoir thickness and porosity. These distributions are restricted to potential accumulations larger than 50 million barrels of in-place oil (MMBO) or 250 billion cubic feet (BCF) of technically recoverable gas for remote areas of the Arctic, and 5 million barrels of oil and $100 \mathrm{BCF}$ in areas that have considerable infrastructure, such as the central Alaska North Slope (Bird and Houseknecht, 2005).

Resulting distributions are risked, using a procedure designed to weigh the likelihood that geologic parameters were sufficient to generate at least the minimum-size accumulation. In turn, probabilistic estimates of in-place petroleum resources are calculated on the basis of the risked distributions of size and number of potential petroleum accumulations in each play. A recovery factor appropriate to each play is applied to the estimates of in-place petroleum resources to calculate technically recoverable petroleum resources. Typically, $30 \%$ to $50 \%$ of the in-place oil resources and about $60 \%$ to $70 \%$ of in-place gas resources are technically recoverable. Estimates for each play are aggregated to calculate total technically recoverable petroleum resources for each assessment area.

The USGS has published resource estimates only for portions of the offshore Arctic that include the south Kara/Yamal, Barents Sea, Timan-Pechora, Lapteve Sea Shelf, eastern Greenland and western Greenland/eastern Canada areas. The estimates for these areas have a range of uncertainty of almost an order of magnitude. The Laptev Sea Shelf Province was assessed for undiscovered crude oil, natural gas, and natural gas liquids/condensates resources (collectively referred to as petroleum) as part of the U.S. Geological Survey's Circum-Arctic Oil and Gas Resource Appraisal (CARA) (Klett, et al., 2007). Using a geology-based methodology, the USGS estimates the mean undiscovered, conventional petroleum resources in the province to be approximately 9,300 million barrels of oil equivalent, including approximately 3,069 million barrels of crude oil, 32,252 billion cubic feet of natural gas, and 861 million barrels of natural gas liquids. The USGS also completed an assessment of the potential for undiscovered, technically recoverable (assuming the absence of sea ice) oil and gas resources in the East Greenland Rift 
Basins Province. This study, which supersedes the previous USGS assessment of the same area completed in 2000, was necessary because of new information made available through collaboration with the Geological Survey of Denmark and Greenland (GEUS), which significantly changes the geological understanding of the area. As defined for CARA, the province includes an area of approximately 500,000 square kilometers, most of which underlies less than 500 meters of water offshore east of Greenland between $70^{\circ}$ and $82^{\circ}$ North (Gautier, 2007. Figure 2.1 shows the regions assessed by the two studies. The new Circum-Arctic Resource Appraisal by the USGS was released in July 2008, and and include collaboration with the Geologic Survey of Denmark and Greenland (Bird et al. 2008). This new assessment concludes “...that 90 billion barrels of oil, 1,669 trillion cubic feet of natural gas, and 44 billion barrels of natural gas liquids may remain to be found in the Arctic, of which approximately 84 percent is expected to occur in offshore areas." A newly compiled but unpublished map of Arctic sedimentary basins was used to define geologic provinces, each containing more than $3 \mathrm{~km}$ of sedimentary strata.

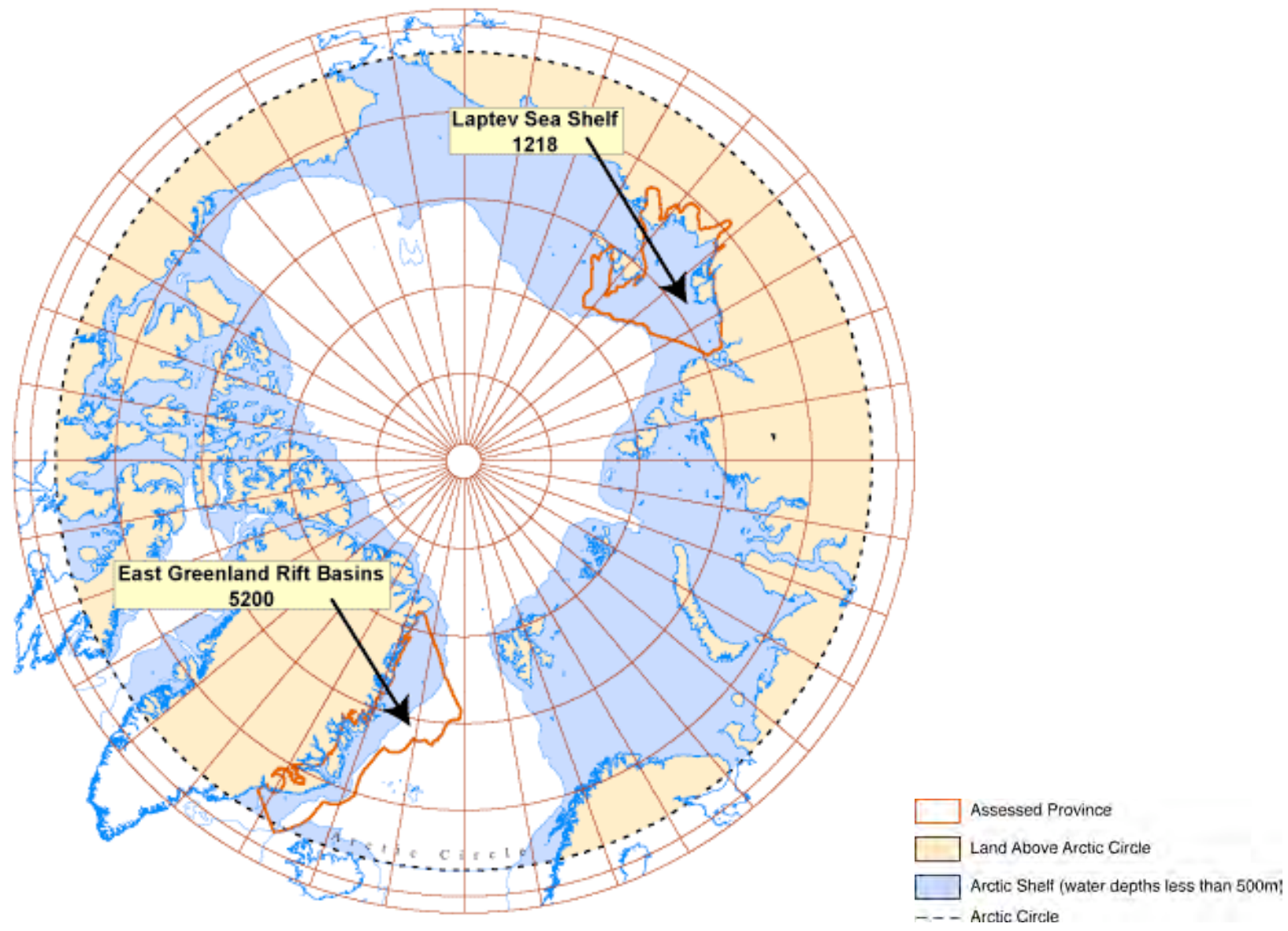

Figure 2.1. Two of the Arctic regions assessed for undiscovered hydrocarbon resources by the USGS (Klett et al., 2007 and Gautier, 2007). 


\subsection{Wood Mackenzie and Fugro Robertson Assessment}

The recent assessment by consultants Wood Mackenzie and Fugro Robertson used a similar methodology, but included a subsurface and commercial review of known resources and estimations of the yet-to-find petroleum potential. They factored in existing infrastructure, full cycle economics, and current cost structure and relied heavily on drilling and production data from current exploration activities (Smith, 2007).

\subsection{Comparison of USGS and Wood Mackenzie Assessments}

The estimates of the absolute overall hydrocarbon potential of the Arctic by the USGS (prior to July 2008) and the Wood Mackenzie Group differ considerably, with the Wood Mackenzie study estimating 178 Giga barrels of oil equivalent (Gboe) across five countries, and the USGS, in its partial assessment of the Arctic, estimating approximately 237 Gboe for a smaller assessed area. A study by the consultant company IHS estimates a total of about 350 Gboe (HIS Energy, 2004), and a review by John Laherrere (2008) estimated a total of 200 Gboe. The USGS estimates perhaps as much as $25 \%$ of the world's undiscovered resources are in the circum Arctic region; Wood Mackenzie estimates closer to 14\%. Both groups estimate that natural gas will likely account for perhaps as much as $75 \%$ of the potential; and both groups assess Arctic Alaska, eastern Greenland, the East and West Barents basins in Norway and Russia and the South Kara/Yamal basins of Russia as having the highest hydrocarbon potential (Gautier, 2007). The Russian Laptev Sea shelf area is not expected to be as rich in hydrocarbons, but is still highly prospective (Dongarov, 2007). Russian gas accounts for $69 \%$ of the total (Cohen, 2007). It is interesting that the Chukchi area between Alaska and Siberia is not an area expected to have particularly large hydrocarbon accumulations, yet because of logistics and leasing opportunity, it is an area of intense exploration activity. Wood Mackenzie forecasts that oil production from all of the polar areas will peak at 3 million barrels per day (Mb/d) and $5 \mathrm{Mboe} / \mathrm{d}$ of gas, at least two decades from now (Cohen, 2007).

Some of the estimations by sub-basin are shown in Table 2.1. Lack of data and distance to industry hubs and infrastructure result in lower potential being assigned to East Siberia, North Chukchi, the northern part of the Laptev Sea, and North Greenland by the USGS and by the Wood Mackenzie study. Increase in data and accessibility with time may result in large resources being recognized here. Although the estimates of recoverable hydrocarbons are given in Giga barrels of oil equivalent, most of the potential resource is gas. Exceptions will be where reservoirs are sourced by oil prone (mostly Silurian or other lower Paleozoic) source rocks.

Table 2.1. Estimates of undiscovered hydrocarbon potential for some of the circum Arctic shelf areas.

\begin{tabular}{||l|l|l||}
\hline \multicolumn{1}{|c||}{ COUNTRY } & \multicolumn{1}{|c||}{$\begin{array}{c}\text { BOE } \\
\text { RECOVERABLE }\end{array}$} & \multicolumn{1}{c||}{ DATA SOURCE } \\
\hline \hline $\begin{array}{l}\text { Greater Arctic } \\
\text { Alaska }\end{array}$ & 117 Gboe & $\begin{array}{l}\text { http://www.mms.gov/alaska/re/reports/GSA/Abstract__ } \\
\text { Geoph_Soc_Alaska_06apr'06.pdf }\end{array}$ \\
\hline $\begin{array}{l}\text { ANWR plus } \\
\text { National } \\
\text { Petroleum Reserve }\end{array}$ & $\begin{array}{l}7.7 \text { Gboe, } 4 \\
\text { TCF gas }\end{array}$ & USGS FS2005-1217 \\
\hline Mackenzie Basin & $\begin{array}{l}\text { 14G+333 Mboe } \\
\text { gas }\end{array}$ & USGS FS2006-302 \\
\hline
\end{tabular}




\begin{tabular}{||l|l|l||}
\hline $\begin{array}{l}\text { East Greenland rift } \\
\text { basin }\end{array}$ & 17.3 Gboe & USGS FS07-3077-508 (9 oil, 8 condensate, 86 TCF) \\
\hline Chukchi Sea & 15.3 Gboe & http://www.petroleumnews.com/pntruncate/328947931.shtml \\
\hline $\begin{array}{l}\text { Norwegian } \\
\text { Barents Sea }\end{array}$ & 6.2 Bboe & $\begin{array}{l}\text { http://energy.ihs.com/News/published- } \\
\text { articles/articles/norwegian-barents-sea-historical-overview- } \\
\text { future-perspectives.htm }\end{array}$ \\
\hline $\begin{array}{l}\text { West Siberia Kara } \\
\text { Sea }\end{array}$ & 185 Bboe & $\begin{array}{l}\text { http://energy.ihs.com/NR/rdonlyres/EAA73544-7131-4B78- } \\
\text { 92B5-DBB9FF5308B3/0/fraser_russia.pdf }\end{array}$ \\
\hline East Siberian Sea & $50+$ Bboe & $\begin{array}{l}\text { http://energy.ihs.com/NR/rdonlyres/EAA73544-7131-4B78- } \\
\text { 92B5-DBB9FF5308B3/0/fraser_russia.pdf }\end{array}$ \\
\hline
\end{tabular}

\subsection{Methane Gas Hydrate Assessments}

Assessment methodologies for recoverable reserves of methane gas hydrates are still being developed. The USGS 1995 National Assessment of United States Oil and Gas Resources (Collett, 1995) contained, for the first time, an assessment of the in-place methane gas hydrate resources of the U.S. onshore and offshore regions (Figure 2.2). The offshore gas hydrate region included the continental shelf offshore northern Alaska, with an estimated 168,500 trillion cubic feet (TCF). Actual recoverable is expected to be much lower due to the difficulty in recovering gas hydrate in low concentrations. The USGS Energy Program is working with the Mineral Management Service to develop standardized assessment methodology of in-place resource.

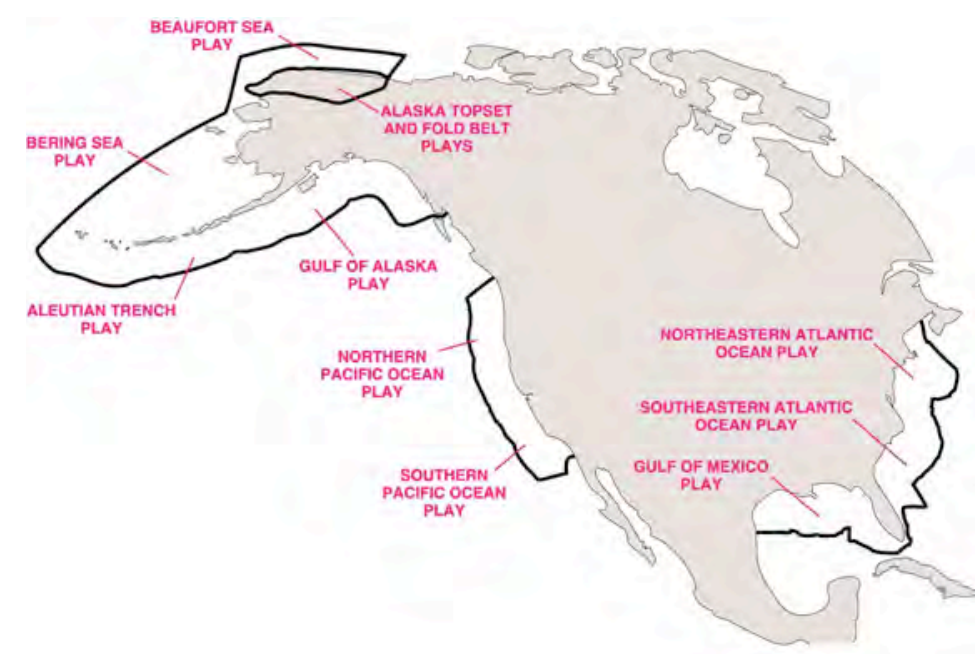

Figure 2.2. Offshore areas assessed by the USGS for in-place volumes of methane gas hydrates (Collett, 1995).

The DOE and the US Energy Information Administration (EIA, 1998) summarized nonstandardized global estimates of methane in hydrates. The estimates for oceanic deposits are shown in Table 2.2, and vary by over an order of magnitude. More recently, the Geological Survey of Canada (Osadetz and Chen, 2005) used both deterministic spatial and reservoir parameter probabilistic models to assess in-place hydrate volumes for the Beaufort Sea-Mackenzie Delta. Their deterministically estimated total gas hydrate gas-in-place resource for this area is $8.82 \times 10^{12} \mathrm{~m}^{3}$. 
Recently, Wood and Jung (2008) have published a global estimate of gas hydrate distribution. Their global gas hydrate estimate is $4.47 \times 10^{5} \mathrm{~km}^{3}$ of solid methane hydrate or $2.6 \times 10^{6}$ TCF of methane gas, or 40 terratons of carbon (TtC) globally. They do not break out their estimate by region and we have not yet been able to interrogate their model results to determine the distribution of marine gas hydrate in the Arctic. However, they did not include gas hydrate beneath marine permafrost (Wood, personal communication).

Table 2.2. Estimates of Gobal Oceanic Reserves of Methane in Natural Gas Hydrates in 100,000 Trillion Cubic Feet (After EIA, 1998).

\begin{tabular}{||l|l||}
\hline Date of Estimate/Source & Oceanic Deposits \\
\hline \hline 1977/Trofimuk et al & 1.8 to 8.8 \\
\hline 1981/McIver & 1.1 \\
\hline 1988/Kvenvolden & 6.2 \\
\hline 1990/MacDonald & 6.9 \\
\hline 1994/Gornitz and Fung & $9.3-49.1$ \\
\hline
\end{tabular}





\subsection{Geospatial Analysis of Potential Hydrocarbon Resources}

Previous hydrocarbon potential assessments of the arctic region such as those done by the USGS and Wood Mackenzie have been focused on conventional oil and gas resources. These do not include the potential resources of natural gas trapped by hydrates. However, as the world's combustible energy resource base shifts from oil to gas, exploitation of offshore methane gas hydrates from marine sediment will likely occur (Max and Lowrie, 1992). Recent surveys by the USGS have estimated that reserves of methane in hydrate form exceed all other fossil fuel forms of organic carbon (Booth et al., 1996), although globally much of that hydrate resource is in sub-economic stratigraphic accumulations (Milkov and Sassen, 2002). Independent estimates of the natural gas hydrate potential have suggested that as much as $8,833,572 \mathrm{~km}^{3}$ of potential methane in hydrate is present in the Arctic. In this study, we integrate published estimates of conventional oil and gas potential with knowledge about methane gas hydrate occurrence to construct a preliminary geospatial analysis that can facilitate the prediction of hydrocarbon development and exploitation in the Arctic Region. Geopolitical information as well as geologic and infrastructure data available from published sources were considered in this analysis.

\subsection{Approach and Methods}

Our approach to this study was to gather existing, publicly available data and combine these data with other sources to provide the basis for generating maps of hydrocarbon potential in the Arctic Region. We used Environmental Systems Research Institute, Inc. (ESRI) ArcGIS to spatially analyze the data and create maps that were subsequently converted to Keyhole Markup Language (KML) files that can be imported into Google Earth. We began by assembling basemap data from several sources that would provide the basis for our map products. Fundamental basemaps to provide general reference only, such as country outlines and latitude and longitude lines, are from ESRI's ArcWorld digital map. The digital grid of the bathymetry of the arctic region was acquired from the International Bathymetric Chart of the Arctic Ocean (Jakobsson, et al., 2008). Figure 3.1 shows the data presented by depth regions representing deep to shallow water, land and ice cover. Geologic Basins and Rock type data layers were acquired from coverages generated by the USGS as part of the Open File Report on Oil and Gas Fields of the Arctic (Persits and Ulmishek, 2003). We eliminated geologic provinces that have no likelihood of producing oil and gas, and areas containing igneous rock outcrops (shown in red), thus creating a base layer of sedimentary basins having potential for hydrocarbon deposits (Figure 3.2). The main purpose of Figure 3.2 is to illustrate the geologic complexity of the Arctic region. Our study is necessarily a simplification of that complexity. Note in particular, that we focus on marine hydrocarbon resources in order to facilitate understanding of the effect of waning sea ice on the location and intensity of off-shore development. Because we are primarily interested in offshore hydrocarbon deposits, most maps are cropped by countries, shown in beige. However, we recognize that off-shore development cannot be entirely separated from on-shore infrastructure. 


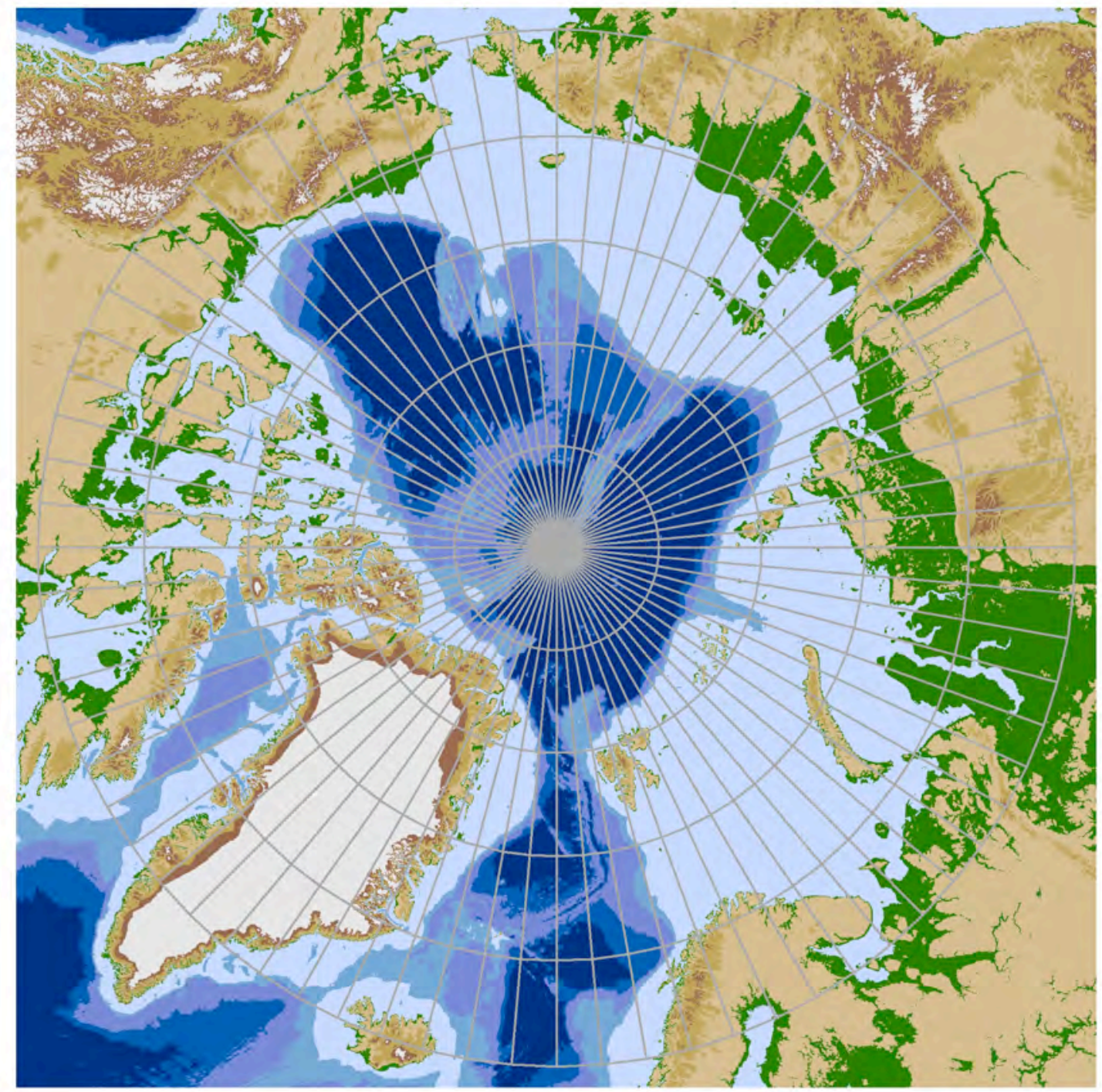

Legend

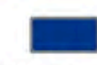

$-5,500 m$ to $-3,000 m-2,499 m$ to $-1,500 m-499 m$ to $0 m-101 m$ to $500 m \quad 1,001 m$ to $1,500 m$

$-2,999 m$ to $-2,500 m-1,499 m$ to $-500 m$ om to $100 m$ $501 m$ to $1,000 m 1,501 m$ to $3,000 m$

Figure 3.1. Bathymetry and Topography of the Arctic Region (based on data from Jakobsson, et al., 2008) 


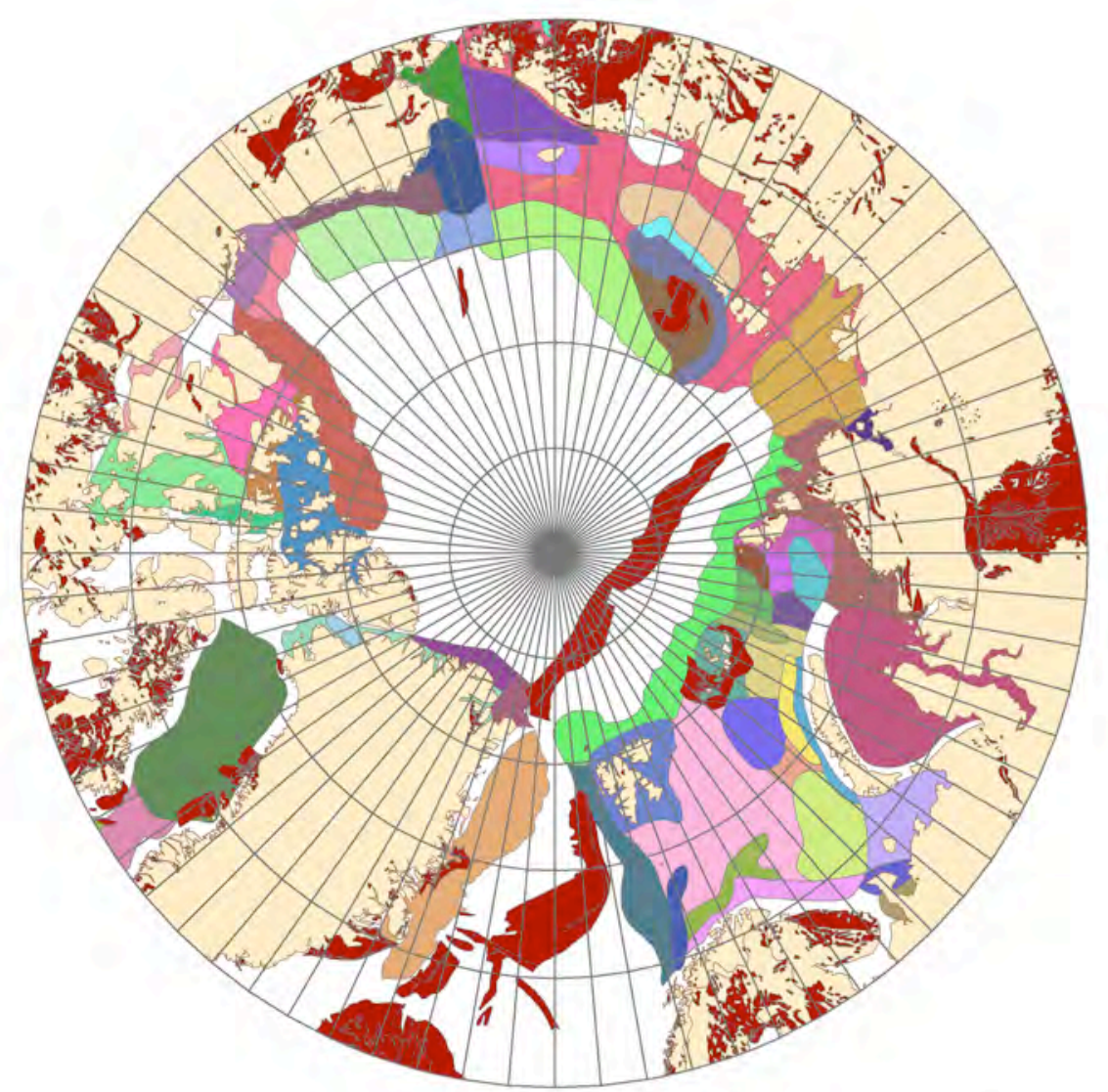

\begin{tabular}{|c|c|c|c|}
\hline & Legen & & \\
\hline$\square$ & n & $\square$ & 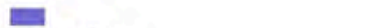 \\
\hline Admiralty Arch & De Long High & North Chukchi Basin & Timan High \\
\hline 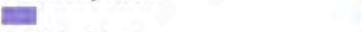 & 迹 & 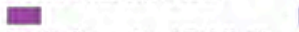 & 四 \\
\hline Anabar Basin & East Greenland Rift Basins & North Greenland Foldbelt & Timan-Pechora Basin \\
\hline Anzhu Uplift & Grumant Uplift & North Greenland Platform & Troms-Bjornoya Basin \\
\hline Arctic Coastal Shelf & Hammerfest-Varanger Basin & North Novaya Zemlya Basin & Uedineniya Basin \\
\hline Arctic Ocean Slope & Hope Basin OCS & Novaya Zemlya Monocline & Ushakov High \\
\hline Baffin Basin & Kane Basin & Novosibirsk Basin & Verkhoyan-Chukotka Folded Region \\
\hline Banks Basin & Khatanga Saddle & Parry Island Foldbelt & Vize High \\
\hline Barents Continental Slope & Kola Monocline-Finnmark Platform & Schmidt Basin & Wandel Sea Basin \\
\hline Beaufort Shelf OCS & Koryak-Kamchatka Foldbelt & Severnaya Zemlya High & West Greenland Basin \\
\hline Blagoveshchensk Basin & Labrador-Newfoundland Shelf & South Arctic Basin & West Siberian Basin \\
\hline Canada Basin-Beaufort Slope OCS & Laptev Shelf & South Barents Basin & Wollaston Basin \\
\hline Central Barents Platform & Ludlov Saddle & South Chukchi-Hope Basin & Wrangel Basin \\
\hline Central Kara High & Mackenzie Delta & St. Anna Basin & Wrangel-Herald Uplift \\
\hline Chukchi Borderland OCS & Mackenzie Delta Slope & Svalbard High & igneous rock \\
\hline Chukchi Shelf OcS & Mezen Basin & Sverdrup Basin & \\
\hline Cornwallis Foldbelt & North Barents Basin & Taimyr-Kara High & \\
\hline
\end{tabular}

Figure 3.2. Geologic Provinces with possibility of oil and gas resources and areas of igneous rock outcrops representing unlikely hydrocarbon occurrence (based on digital data from Persits and Ulmishek, 2003) 


\subsection{Conventional Oil and Gas}

We examined the summary comparison of estimated oil and gas reserves in the Arctic as reported by four different groups. Two of these (USGS and Wood Mackenzie) have good summaries in map form. The Wood Mackenzie assessments and maps were more conservative and more complete. Using their maps as a base, we included the location of igneous rocks, structural boundaries, and sediment age and thickness to produce a hydrocarbon potential map. The greatest uncertainties associated with this map are due to lack of available data for parts of the Russian shelf in the Wood Mackenzie study, and the fact that USGS studies are still ongoing. A comparison of assessments of Wood Mackenzie and the USGS by two additional groups (IHS and John Laherrere, 2008) gave us additional confidence in the maps.

The results of comparing assessments and modulating relative estimates of hydrocarbon potential by eliminating areas of basement rocks or thin sedimentary accumulations is shown in Figure 3.3. The assignments reflect sediment thickness, known water depth, successful exploration activity, and infrastructure.

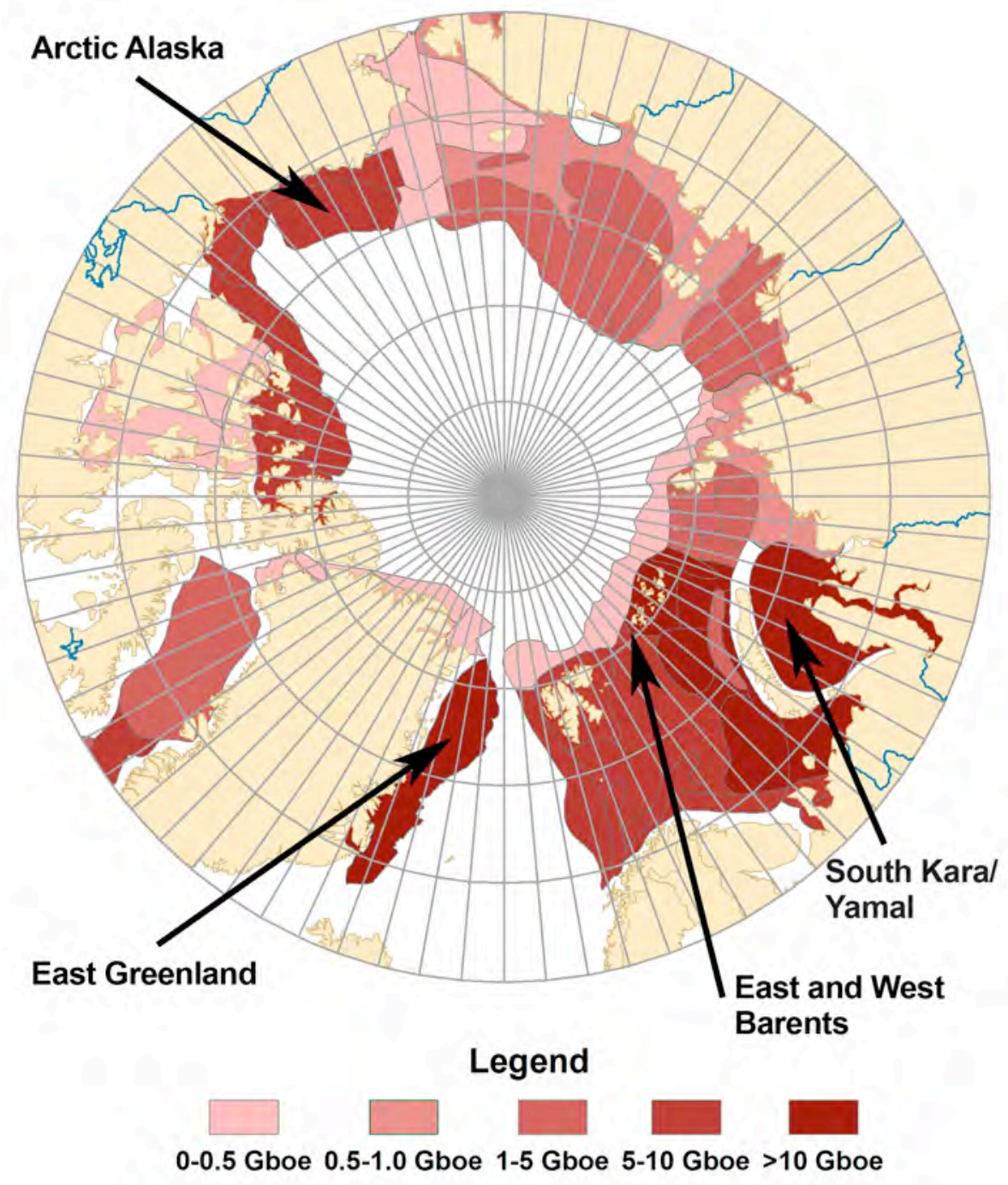

Figure 3.3. Conventional Oil and Gas Potential of Undiscovered Fields in Gboe per field. 


\subsection{Methane Gas Hydrates}

The approach to mapping potential methane gas hydrate occurrence in the polar region is based on Wood and Jung (2008) as shown in Figure 3.4 and on bathymetry modeling adapted from Romanovskii et al. (2005). Both Max and Lowrie (1993) and Wood and Jung (2008) directed their attention to nonpermafrost related factors controlling gas hydrate occurrence in the marine environment. Sediment thickness and global heat flow were key factors in developing the three areas shown in Figure 3.4 which shows the estimated thickness of gas hydrate stability zone. While this is roughly similar to the map of Max and Lowrie (1993), we use Wood and Jung (2008) as the current best estimate of gas hydrate distribution in Arctic Ocean outside of areas of marine permafrost.
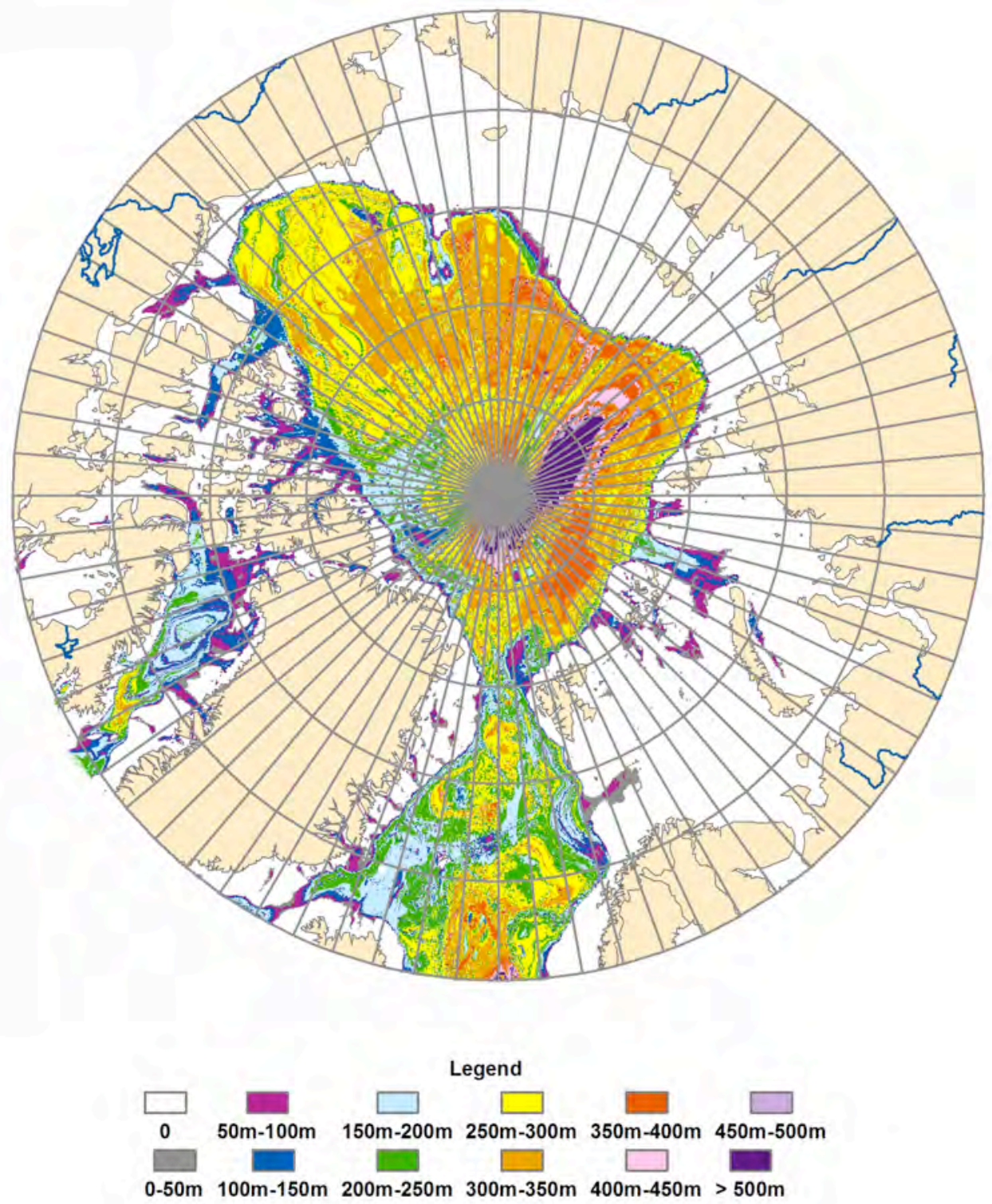

Figure 3.4 Arctic gas hydrate potential (from Wood and Jung, 2008) shown as an estimated thicknes of the gas hydrate stability zone in marine sediments. Submarine permafrost gas hydrate potential is not included in this map. See Figure 3.6 for gas hydrate potential associated with submarine permafrost. 
Romanovskii et al. (2005) focused on the East Siberia Arctic Shelf (Figure 3.5), which has a flat bathymetry and relatively shallow water depths (not exceeding $100 \mathrm{~m}$ ) and which can extend over 1000 $\mathrm{km}$ from the shoreline. By reconstructing the permafrost evolution over the last 400,000 years, these authors modeled the evolution of the gas hydrate stability zone as well. Their results show conditions are favorable for a continuous thick zone $(\sim 200 \mathrm{~m})$ of stable gas hydrates in water depths up to $60 \mathrm{~m}$. An average geothermal gradient flux of $70 \mathrm{~mW} / \mathrm{m}^{2}$ was used for their calculations.

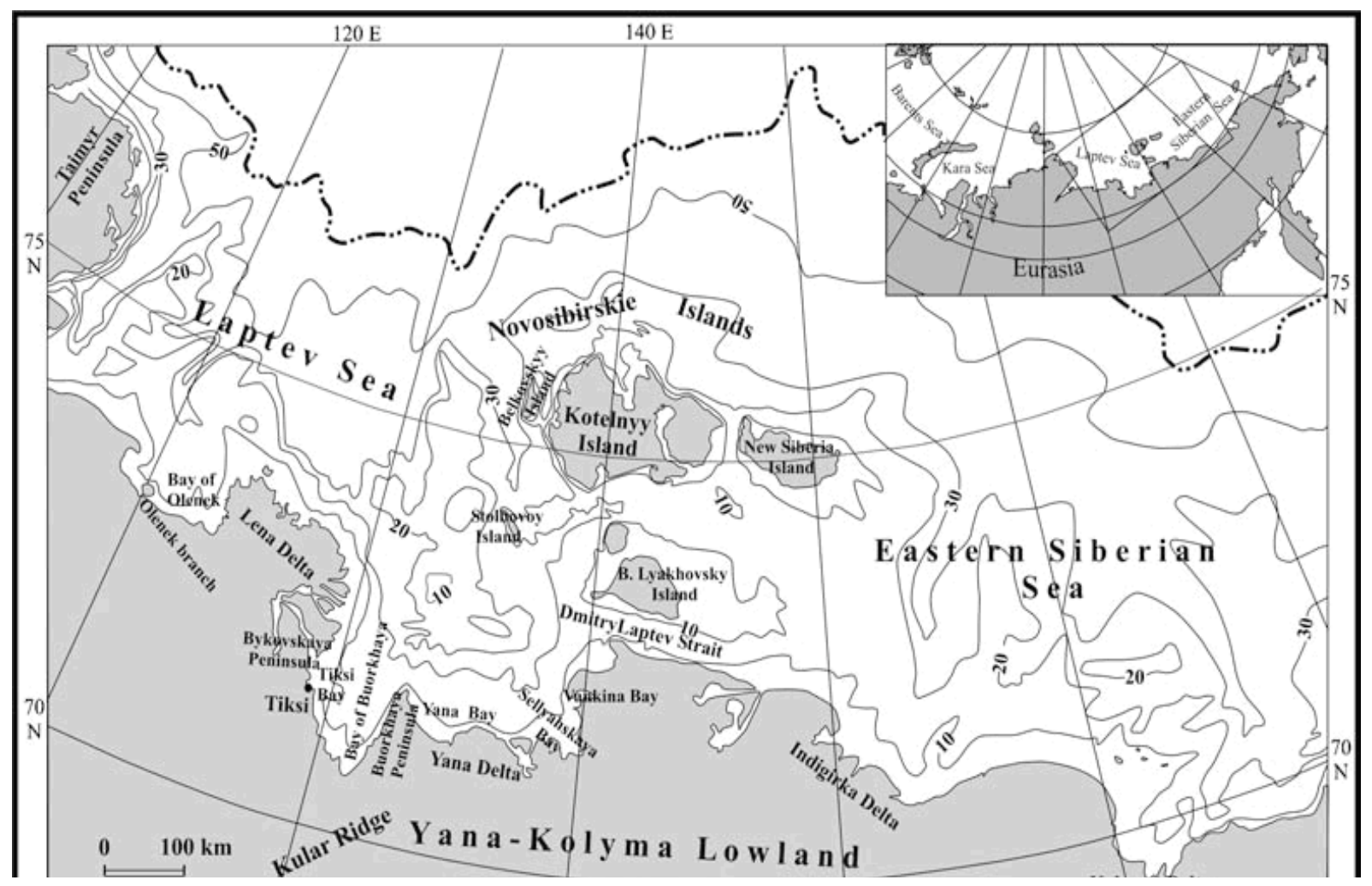

Figure 3.5. Index map of investigation area (taken from Romanovskii et al., 2005)

Building on the research presented by Romanovskii et al. (2005), we developed a map of potential methane gas hydrate occurrence for the entire arctic shelf (Figure 3.6). The criteria were selected based on modeling results by Romanovskii et al. (2005) that suggested the arctic shelf is underlain by relic permafrost stable enough to support gas hydrate formation. It should be noted that inflow of rivers (shown in Figure 3.6) and active tectonic zones, which would be dominant factors controlling hydrate stability, were not considered because of scale. The dark blue color in Figure 3.6 represents the highest potential for continuous methane gas hydrate occurrence, the lighter blue shades represent progressively less favorable conditions. Boundaries for the thick $(200 \mathrm{~m})$ hydrate deposit (dark blue) are confined to water depths greater than $30 \mathrm{~m}$ and less than or equal to $100 \mathrm{~m}$. Romanovskii et al. (2005) did not eliminate the 0-30m water depth zone. We have given this zone a lower hydrate occurrence probability to more appropriately categorize estuaries and near shore environments where the thermal regime may not favor gas hydrate stability. Gas hydrate is also less likely to be present in water depths between $100 \mathrm{~m}$ and $200 \mathrm{~m}$ where methane gas hydrate bearing formations are expected to be patchy and discontinuous. The lightest blue color shows areas of water depth between 0 to $30 \mathrm{~m}$. For the purposes of this analysis we consider the 0 to $30 \mathrm{~m}$ water depth and the 100 to $200 \mathrm{~m}$ water depths to have similar gas hydrate potential. 
Generally, in this shallow shelf submarine permafrost setting, conditions favorable for methane gas hydrate are expected to be minimal in water depths greater than $200 \mathrm{~m}$. Again, it is important to note that this approach is highly simplified and used by analogy with the results of Romanovskii et al. (2005). It does not take into account the role of tectonic or other geologic factors which are expected to locally concentrate or dissipate gas hydrate. We have also assumed that permafrost-controlled hydrate does not occur south of $67.5^{\circ}$ North latitude.

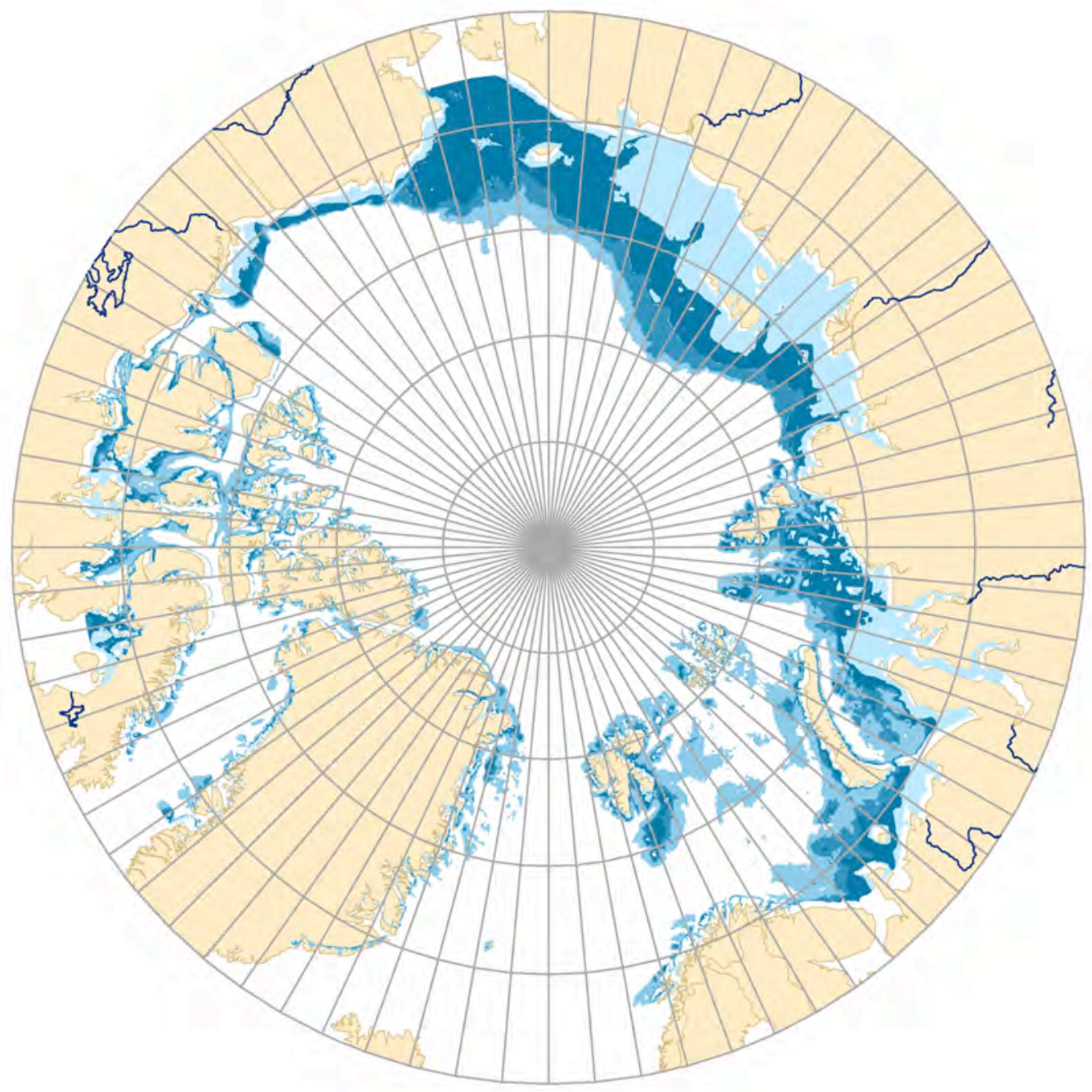

Legend

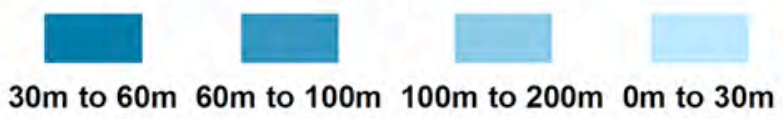

Figure 3.6. Bathymetric Ranges Defining Continental Shelf Regions with Gas Hydrate Potential Associated with Submarine Permafrost. The near shore 0 to $30 \mathrm{~m}$ depths are considered to have approximately the same potential for gas hydrate as the 100 to $200 \mathrm{~m}$ depths as explained in the text. 


\subsection{Combining Conventional Oil and Gas with Methane Gas Hydrate Resources}

The final hydrocarbon potential map (Figure 3.7) was formed by combining the oil and gas potential with the methane gas hydrate maps described in the previous section. The maximum hydrate stability potential (30 to $100 \mathrm{~m}$ water depth, and the areas identified in Wood and Jung (2008)) were overlain in transparent blue and purple colors on the five areas that represent different levels of oil and gas potential (shades of red Figure 3.3). The potential for gas hydrate is, of course, uncertain due to timing and intensity of fractures that allow methane to escape from sedimentary rocks and to form hydrates near the surface, as well as from the presence of river discharge that destroys the preservation of permafrost. It should also be noted that very young strictly biogenic methane hydrates may form in Pleistocene deltas or depocenters. Figure 3.3 and 3.7 do not reflect sub-basin details in conventional hydrocarbon potential because such information typically is available only from detailed studies and eventually from production data in specific producing fields.

The shallow depth of the offshore continental shelf is the most important control on hydrate accumulation in the Arctic; much of the potential of the shallow shelf is in relict accumulations, related to subaerial exposure of the shelf and formation of permafrost and hydrates. The hydrates in the permafrost are preserved by the Late Pleistocene and Holocene sea level rise. Presence of faults in hydrocarbon bearing sedimentary rocks may increase the likelihood of methane as hydrate formation (Osadetz and Chen, 2005), particularly if the faulting is related to relatively late breaching of hydrocarbon reservoirs. 


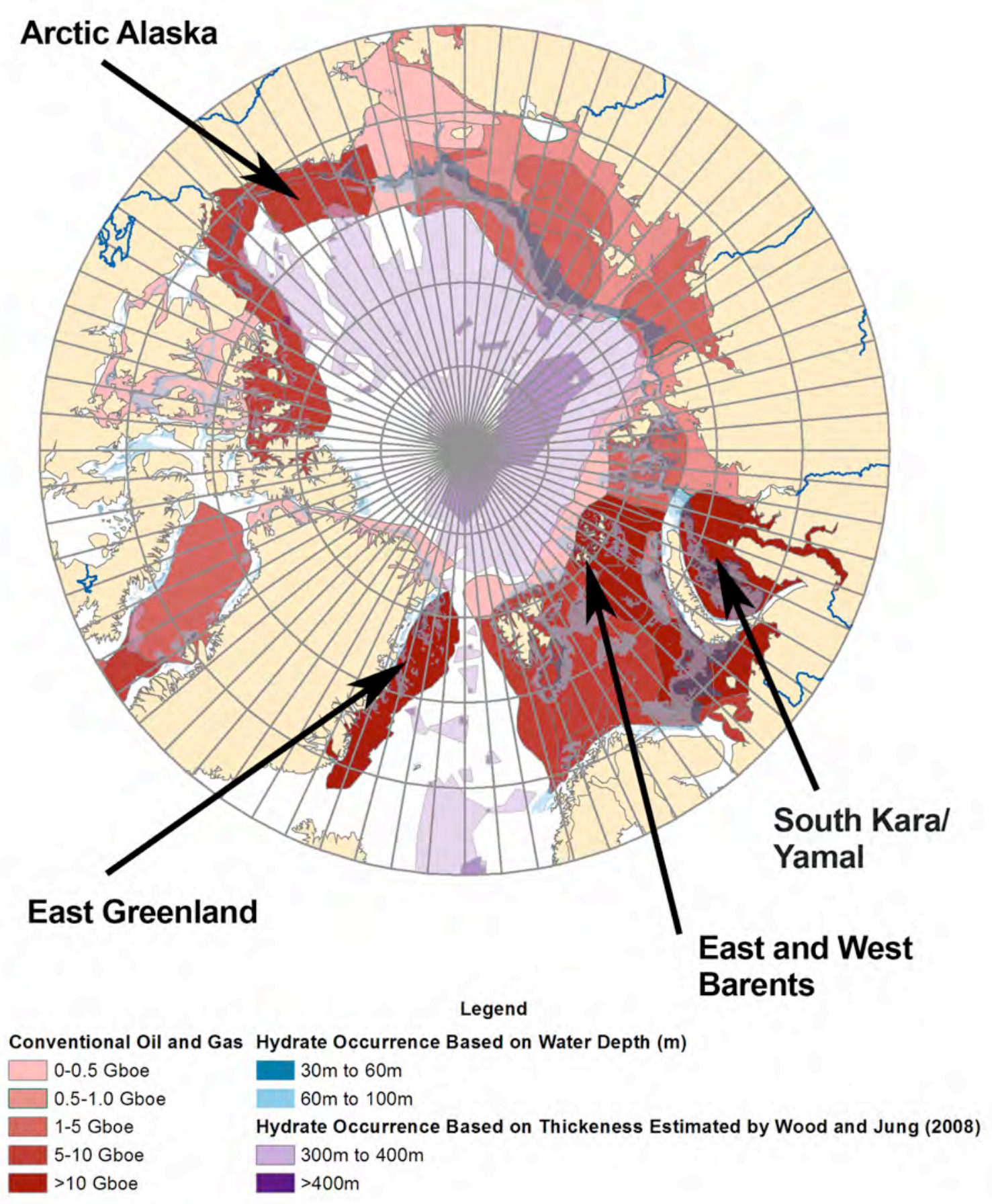

Figure 3.7. Hydrocarbon potential showing combined methane hydrate and conventional oil and gas potential. Rivers are shown in dark blue. Hydrate potential includes predicted hydrate thickness in deeper sediments ( $300 \mathrm{~m}$ to $400 \mathrm{~m}$ and $>400 \mathrm{~m}$ hydrate thickness) from Wood and Jung (2008); and predicted regions of hydrate accumulation based on estimates of Romanovskii et al. (2005), water depths of 30 to $60 \mathrm{~m}$ and 60 to $100 \mathrm{~m}$. See text for additional discussion of how this map was generated. 


\subsection{Overlaying Images in Google Earth}

One approach to view geospatial images is to drape them over the world map provided in Google Earth or other geographic data viewer. Figures 3.3, 3.6 and 3.7 were all converted to Keyhole Markup Language (KML) format to be compatible with Google Earth, ArcExplorer or other geographic data viewers. These images can be viewed layer by layer and scale as the data viewer zoom features are used. A CD containing the generated maps as both images and in KML format is included with this document. Appendix A contains an index of the files included on the CD. 


\subsection{Future Work}

Available data on hydrocarbon resources in the Arctic Ocean make possible a preliminary geospatial analysis that can facilitate the prediction of hydrocarbon development and exploitation in the region. The combination of conventional oil and gas resources with potential gas hydrate resources has not been attempted previously and is particularly powerful as the likelihood of gas production from shallow methane gas hydrates increases. Available or planned infrastructure, such as pipelines, combined with the geospatial distribution of hydrocarbons is a very strong determinant of the temporal-spatial development of Arctic hydrocarbon resources. Current infrastructure is well known. However, future infrastructure is partly controlled by geopolitics and governmental decisions, making it difficult to predict. Overall conclusions from this study are summarized as follows:

- The most significant areas are those with highest hydrocarbon potential and the best current and planned infrastructure.

- Depth of water is critical in the economics of exploration; the shallow continental shelf is not only more attractive economically, it is also where the greatest hydrocarbon potential is located, including gas hydrates.

- Geographic areas with the highest potential are Arctic Alaska, eastern Greenland, the East and West Barents basins in Norway and Russia, and the South Kara/Yamal basins of Russia

Significant unknowns decrease the certainty of predictions for development of hydrocarbon resources. These include:

- Areas in the Russian Arctic that are poorly mapped

- Disputed ownership: primarily the Lomonosov Ridge

- Lack of detailed information on gas hydrate distribution

- Technical risk associated with the ability to extract methane gas from gas hydrates

Logistics may control areas of exploration more than hydrocarbon potential. Accessibility, established ownership, and leasing of exploration blocks may trump quality of source rock, reservoir, and size of target. With this in mind, the main areas without highest potential that are likely to be explored first are the Bering Strait and Chukchi Sea. Issues specific to these areas include ecology of polar bears and other environmental issues. Furthermore, fields in the Bering Strait and north are likely to be fairly small. Stepout drilling may shift exploration emphasis and result in some areas being drilled sooner, if step outs result in high pay in specific areas. For the top ranked areas, step out drilling is not likely to change their overall prospectivity.

Methane hydrate potential is largely confined to the shallow continental shelf that also contains the greatest hydrocarbon potential. Commercial hydrate exploitation is likely to benefit from the development of conventional resource infrastructure, especially since about $75 \%$ of that resource is expected to be gas, rather than liquids. However, in areas where continued global warming allows warmer currents to enter the Arctic basin, the presence of hydrates could actually pose drilling challenges ranging from minor gas bubbling to borehole instability to safety hazards for drilling platforms. Dissociation of gas hydrates may contribute to the destabilization of sediment and massive slope failures, as in the Storegga submarine slide off west-central Norway (Hutchinson and Hart, 2003). 
Future research on development of Arctic hydrocarbon resources could be focused in three main areas: 1) refining hydrocarbon potential on a basin-by-basin basis, 2) developing more realistic and detailed distribution of gas hydrate, and 3) assessing the likely future scenarios for development of infrastructure and their interaction with hydrocarbon potential. It would also be useful to develop a more sophisticated approach to merging conventional and gas hydrate resource potential that considers the technical uncertainty associated with exploitation of gas hydrate resources. Taken together, these areas could further improve our understanding of the exploitation of Arctic hydrocarbons as ice-free areas increase in the future. 


\subsection{References}

Bird, K.J., and Houseknecht, D.W., 2005. "Oil and gas assessment of central North Slope, Alaska, 2005." U.S. Geological Survey Fact Sheet 2005-3043, 2 p., <http://pubs.usgs.gov/fs/2005/3043/>.

Bird, Kenneth J., Ronald R. Charpentier, Donald L. Gautier, David W. Houseknecht, Timothy R. Klett, Janet K. Pitman, Thomas E. Moore, Christopher J. Schenk, Marilyn E. Tennyson, and Craig J. Wandrey, 2008. "Circum-Arctic Resource Appraisal: Estimates of Undiscovered Oil and Gas North of the Arctic Circle." U.S. Geological Survey, Fact Sheet 2008-3049

Booth, J.S., Rowe, M.M., Fischer, K.M. 1996. Offshore gas hydrate sample database with an overview and preliminary analysis. U.S. Geological Survey, Open File Report 96-272, Denver, Colorado.

Cohen, D. 2007. “Arctic Dreams” Energy Bulletin 25 April 2007. 25 April 2007.

<http://www.energybulletin.net/29151.html>

Collett, T.S.. 1995. "Gas hydrate resources of the United States”. in Gautier, D.L., Dolton, G.L., Takahashi, K.I., and Varnes, K.L., eds., 1995 National assessment of United States oil and gas resources on CD-ROM: U.S. Geological Survey Digital Data Series 30.

Collett, Timothy, 2008, "Geologic and Engineering Controls on the Production of Permafrost-Associated Gas Hydrate Accumulations." Proceedings of the 6th International Conference on Gas Hydrates (ICGH 2008), Vancouver, British Columbia, CANADA, July 6-10, 2008.

Dongarov, Edward. "Laptev Sea: A Frontier Arctic Basin.” geoexpro.com. September 2007. 12 May 2008. <http://www.geoexpro.com/sfiles/1/08/7/file/LaptevSea_p36.pdf>.

Energy Information Administration, International Energy Outlook 1998, DOE/EIA-0484(98)

(Washington, DC, April 1998).

Franke, D., K. Hinz, and C. Reichert. 2004. "Geology of the East Siberian Sea, Russian Arctic, from seismic images: Structures, evolution, and implications for the evolution of the Arctic Ocean Basin." Journal of Geophysical Research. Vol. 109, pp. B07106.

Friend, Phaedra. "Chukchi Sea Lease Sale Draws Record Bids.” RIGZONE.com. 6 February 2008. 20 May, 2008. <http://www.rigzone.com/news/article.asp?a_id=56399>.

Gautier, D.L., 2007, Assessment of undiscovered oil and gas resources of the East Greenland Rift Basins Province: U.S. Geological Survey Fact Sheet 2007-3077, 4 p.

Gornitz, V. and I. Fung, 1994. "Potential distribution of methane hydrates in the world's oceans." Global Biogeochemical Cycles 8 (3) (1994), pp. 335-347.

Gramling. Carolyn. (2007). "Cold wars: Russia claims Arctic land.” Geotimes. Web Extra, August 1, 2007. < http://www.geotimes.org/aug07/article.html?id=WebExtra080107.html>

Hutchenson, D., and P. Hart. 2003. "Gas Hydrate in the Northern Gulf of Mexico Has Puzzling Characteristics and Could Pose a Hazard to Deep Drilling" USGS Soundwaves Monthly Newsletter. July 2003. < http://soundwaves.usgs.gov/2003/07/fieldwork.html>. 
“IHS Energy's Report on 10-Year Petroleum Trends (1994-2003) Highlights Increased Oil and Gas Production and a Healthy Remaining Global Resource Base.” 18 October 2004

<http://energy.ihs.com/News/Press-Releases/2004/pr_101804-trends.htm>

Jakobsson, M., Macnab, R., Mayer, M., Anderson, R., Edwards, M., Hatzky, J., Schenke, H-W., and Johnson, P., 2008, An Improved Bathymetric Portrayal of the Arctic Ocean: Implications for ocean modeling and geological, geophysical and oceanographic analyses, Geophysical Research Letters (35), < http://www.ibcao.org>

Klett, T.R., and others, 2007, Assessment of Undiscovered Petroleum Resources of the Laptev Sea Shelf Province, Russian Federation: U.S. Geological Survey Fact Sheet 2007-3096.

Laherrere, Jean. "Arctic Oil and Gas Ultimates.” The Oil Drum: Europe. 12 March 2008. <http://europe.theoildrum.com/node/3666>

Kvenvolden, K.A., 1995. "A review of the geochemistry of methane in natural gas hydrate." Organic Geochemistry (23): 997.

Kvenvolden, K. A.1988. "Methane hydrates and global climate.” Global Biochemical Cycles; (2):221229.

McIver, R.D. 1981. "Gas hydrates" in Meyer, R.F., and Olson, J.C., eds., Long-term energy resources: Pitman, Boston, p. 713-726.

MacDonald, G.J. 1990. “The Future of Methane as an Energy Resource.” Annual Review of Energy (15):. 53-83.

Max, M.D. and A. Lowrie, 1992. "Natural Gas Hydrates: Arctic and Nordic Sea Potential," Arctic Geology and Petroleum Potential, ed. T.O. Vorren et al., Norwegian Petroleum Society, 1992.

Max, M.D. 2000. Natural Gas Hydrate: In Oceanic and Permafrost Environments. Springer, 414p.

Milkov, A.V., and R. Sassen. 2002. "Economic geology of offshore gas hydrate accumulations and provinces." Marine and Petroleum Geology (19): 1-11.

NASA. "Satellites See a Double -Texas Sized Loss in Arctic Sea Ice" 28 September 2005.

<http://www.nasa.gov/vision/earth/environment/arcticice_decline.html>

Osadetz, K.G., and Chen, Z. 2005. "A re-examination of Beaufort Sea-Mackenzie delta basin gas hydrate resource potential using a petroleum play approach", in Proceedings of the 5th International Conference on Gas Hydrate, June 13-16, 2005, Trondheim, Norway, vol. 2.

Persits, F. M. and G. F. Ulmishek. 2003. Maps Showing Geology, Oil and Gas Fields, and Geologic Provinces of The Arctic. U.S. Geological Survey Open File Report 97-470-J

Romanovskii, N. N., H. W. Hubberten, A. V. Gavrilov, A. A. Eliseeva, and G. S. Tipenko. 2005. "Offshore permafrost and gas hydrate stability zone on the shelf of East Siberian Seas." Geo-Marine Letters 25(2-3):167-182.

Sloan, D.E., 1997. Clathrate Hydrates of Natural Gases. Marcel Dekker, Inc, New York. 
Smith, Thomas. "Arctic Dreams - A Reality Check.” geoexpro.com. May 2007. 10 May 2008.

<http://www.geo365.no/sfiles/1/97/7/file/Arctic_Dreams_p16.pdf>

Trofimuk, A.A., N.V Cherskii, and V.P. Tsaryov. 1977. "The Role of Continental Glaciation and Hydrate Formation on Petroleum Occurrence". in Meyer, R.F., ed., The future supply of nature-made petroleum and gas: New York, Pergamon Press, 919-926.

Whaley, Jane. 2007a. "Geological History of the Arctic Ocean." geoexpro.com. September 2007. 10 May 2008. <http://www.geoexpro.com/sfiles/9/97/7/file/HistoryArcticOcean_p60.pdf>.

Whaley, Jane. 2007b."The Azolla Story: Climate Change and More" geoexpro.com. September 2007, p. 66-72. <http://www.geoexpro.com/sfiles/2/97/7/file/Azolla_p66.pdf

Wood, W. T., and Jung, Woo-Yeol, 2008. "Modeling the Extent of Earth's Marine Methane Hydrate Cryosphere." Proceedings of the 6th International Conference on Gas Hydrates (ICGH 2008), Vancouver, British Columbia, CANADA, July 6-10, 2008. 

Appendix A

Index of Electronic Files Provided on CD 



\section{Appendix}

\section{Index of Electronic Files Provided on CD}

Table A.1 shows an index of files provided with this report in electronic format.

Table A.1. Index of electronic files provided on accompanying CD.

\begin{tabular}{||l|l|l||}
\hline \multicolumn{1}{|c|}{ Folder } & \multicolumn{1}{|c||}{ Filename } & \multicolumn{1}{c||}{ Description } \\
\hline \hline figures & fig3.3_oil_gas.jpg,fig3.3_oil_gas.png & Figure 3.3 of this report \\
\hline figures & $\begin{array}{l}\text { fig3.4_marine_hydrate.jpg, } \\
\text { fig3.4_marine_hydrate.png }\end{array}$ & Figure 3.4 of this report \\
\hline figures & $\begin{array}{l}\text { fig3.6_marine_sub_perm_hydrate.jpg, } \\
\text { fig3.6_marine_sub_perm_hydrate.png }\end{array}$ & Figure 3.6 of this report \\
\hline figures & $\begin{array}{l}\text { fig3.7_total_hydrocarbons.jpg, } \\
\text { fig3.7_total_hydrocarbons.png }\end{array}$ & Figure 3.7 of this report \\
\hline kml & fig3.3_oil_gas.kmz & $\begin{array}{l}\text { KML file corresponding to Figure 3.3 for } \\
\text { use with Google Earth }\end{array}$ \\
\hline kml & fig3.6_marine_hydrate.kmz & $\begin{array}{l}\text { KML file corresponding to Figure 3.6 for } \\
\text { use with Google Earth }\end{array}$ \\
\hline $\mathrm{kml}$ & fig3.7_total_hydrocarbons.kmz & $\begin{array}{l}\text { KML file corresponding to Figure 3.7 for } \\
\text { use with Google Earth }\end{array}$ \\
\hline \hline
\end{tabular}





\section{Distribution}

No. of

Copies

100 Pacific Northwest National Laboratory

D.J. Bradley (96)

P.E. Long

H.T. Schaef

E.C. Sullivan

S.K. Wurstner
No. of

Copies
SEQUI

K9-33

K6-81

K6-81

K9-36

Distr.1 




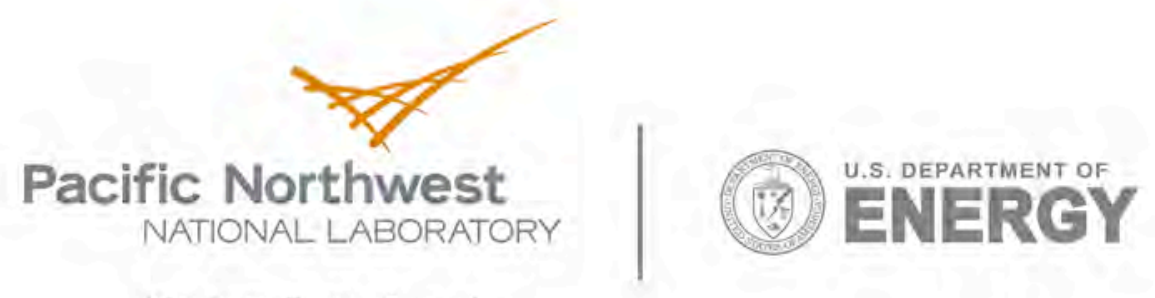

902 Battelle Boulevard

P.O. Box 999

Richland, WA 99352

1-888-375-PNNL (7665)

www.pnl.gov 